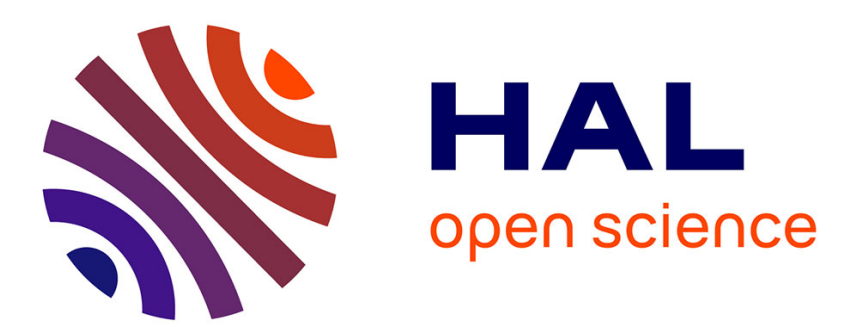

\title{
Spatially explicit bathymetric reconstruction from lead line depth soundings of the late 17th century
}

\author{
Clément Poirier, Thierry Sauzeau, Eric Chaumillon, Bernadette Tessier
}

\section{To cite this version:}

Clément Poirier, Thierry Sauzeau, Eric Chaumillon, Bernadette Tessier. Spatially explicit bathymetric reconstruction from lead line depth soundings of the late 17th century. Estuarine, Coastal and Shelf Science, 2020, 246, pp.107029. 10.1016/j.ecss.2020.107029 . hal-02953058

\section{HAL Id: hal-02953058 \\ https://hal.science/hal-02953058}

Submitted on 18 Dec 2020

HAL is a multi-disciplinary open access archive for the deposit and dissemination of scientific research documents, whether they are published or not. The documents may come from teaching and research institutions in France or abroad, or from public or private research centers.
L'archive ouverte pluridisciplinaire HAL, est destinée au dépôt et à la diffusion de documents scientifiques de niveau recherche, publiés ou non, émanant des établissements d'enseignement et de recherche français ou étrangers, des laboratoires publics ou privés. 


\title{
Spatially explicit bathymetric reconstruction from lead line depth soundings of the late 17th century
}

\author{
Clément Poirier $^{\mathrm{a}, *}$, Thierry Sauzeau ${ }^{\mathrm{b}}$, Eric Chaumillon ${ }^{\mathrm{c}}$, Bernadette Tessier ${ }^{\mathrm{a}}$ \\ ${ }^{a}$ Normandie Univ, UNICAEN, UNIROUEN, CNRS, M2C, 14000, Caen, France \\ ${ }^{\mathrm{b}}$ EA 4270 Centre de Recherche Interdisciplinaire en Histoire, Histoire de l'Art et Musicologie, Université de Poitiers, Université de Limoges, 8 rue René Descartes, 86022 , \\ Poitiers, France \\ ${ }^{\mathrm{c}}$ UMR 7266 LIENSs, CNRS/Université de la Rochelle, 2 rue Olympe de Gouges, 17000, La Rochelle, France
}

\section{A R T I C L E I N F O}

\section{Keywords:}

History

Data archeology

GIS

Shoreline

Charente-Maritime

\begin{abstract}
A B S T R A C T
Sequences of repeated bathymetric surveys through time have been successfully used to document the morphodynamical evolution of coastal environments within historical times. Most chronobathymetric sequences have a restricted temporal coverage, as surveys rarely date back earlier than the 19th century. The aim of this study is to explore the potential of older lead line depth measurements as a reliable source of bathymetric data. A late 17th century marine chart of the Pertuis Charentais (France) was used as a test case. High-resolution scans of the chart sheets were retrieved from a public online digital library. A rare manuscript contemporary to the chart was obtained from the French National Archives, in order to constrain the methodology used to acquire depth measurements. A spatially explicit bathymetry covering $1500 \mathrm{~km}^{2}$ was reconstructed from the interpolation of about 4600 georeferenced depth soundings. Vertical error was estimated by assuming the equivalence of depth values between the late 17th century and the recent (1960) bathymetries above subtidal rocks outcropping on the seafloor. Documentary data indicated that the chart author did not acquire depth measurements on purpose but instead collected data taken by local sailors and coasting pilots over an unknown period of time, probably ranging from a few years to a few decades. The large vertical error estimated to $\pm 4.5 \mathrm{~m}$ mainly resulted from the lack of tide correction. Bathymetric difference maps could not be computed, but despite these weaknesses, the large-scale sediment infilling of the area and the long-term evolution of an estuarine sandbank could be documented, in agreement with previous works. Beyond its utility for local studies, this article provides insights into the processing of depth measurements acquired long before modern hydrography surveys, and demonstrates that such old marine charts deserve consideration, provided conditions are met for their critical assessment.
\end{abstract}

\section{Introduction}

Accurate dating of sediments is essential for constraining records of past environmental changes within robust chronological frameworks. Radiocarbon $\left({ }^{14} \mathrm{C}\right)$ dating is commonly employed for age determination of strata deposited within historical times. In estuarine and coastal environments, ${ }^{14} \mathrm{C}$ age determination is complicated by several methodological impediments, provided unreworked organic material is preserved in the sediment (Olsen et al., 2017). Variability in calibration curves (e.g. Reimer et al., 2013) induces dating uncertainties up to several centuries for samples younger than ca. $600{ }^{14} \mathrm{C}$ years BP. Dating based on the short-lived isotope ${ }^{210} \mathrm{~Pb}$ (Appleby and Oldfield, 1983) and anthropogenic fallout radionuclides ${ }^{137} \mathrm{Cs},{ }^{239,240} \mathrm{Pu}$ and ${ }^{241} \mathrm{Am}$ (e.g. Corcho-Alvarado et al., 2014) is relevant for sediments of the last 100-150 years at best, and require a significant fraction of fine-grained particles in the sediment bulk (Appleby and Oldfield, 1983). Age determination of marine sediments deposited during intermediate historical times (between about 600 and 100 years BP) remains a challenging task. All kinds of alternative, independent chronological markers are therefore welcome. In coastal areas, such markers can be obtained from repeated bathymetric surveys for the last 2 centuries at best (eg. Higgins et al., 2007; Chaumillon et al., 2008a; Guérin et al., 2016). Chronobathymetric sequences are complementary with traditional radiometric dating methods. Although they offer a lower vertical

\footnotetext{
* Corresponding author.

E-mail addresses: clement.poirier@unicaen.fr (C. Poirier), thierry.sauzeau@univ-poitiers.fr (T. Sauzeau), eric.chaumillon@univ-lr.fr (E. Chaumillon), bernadette. tessier@unicaen.fr (B. Tessier).
} 
accuracy and temporal resolution than radiometric dating, they can nonetheless provide spatially explicit reconstructions of sedimentation rates across large areas (tens to hundreds of $\mathrm{km}^{2}$ ), and do not require destructive sampling nor costly analyses (Higgins et al., 2007).

Chronobathymetric sequences have been successfully used to document the morphodynamical evolution of many coastal environments within historical times, including estuaries and estuarine bays (e.g. Bertin and Chaumillon, 2006; Blott et al., 2006; Jaffe et al., 2007; Allard et al., 2010; Tatekoji et al., 2016), micro-to mesotidal lagoons (Allard et al., 2009; Sarretta et al., 2010), tidal inlets (Jaffe et al., 1997; Bertin et al., 2004; Miner et al., 2007; Dallas and Barnard, 2011; Azevedo et al., 2016) and tidal bars of the inner (Billy et al., 2012) and outer estuary (Kapsimalis et al., 2004; Chaumillon et al., 2008a; Guérin et al., 2016), as well as other submarine features like pockmark fields (Brothers et al., 2011) or volcanoes (Watts et al., 2015). Chronobathymetric sequences have proved useful for disentangling the respective contribution of autocyclic (Blott et al., 2006) and allogenic forcing factors on the coasts, including the impact of climate variability (Billy et al., 2012) and human activities (Bertin et al., 2005; Blott et al., 2006; Jaffe et al., 2007; Azevedo et al., 2016; Xie et al., 2017). They have also been used in numerical modelling systems to hindcast past hydrodynamic conditions (Bertin et al., 2005; Tatekoji et al., 2016).

However, most historical bathymetric surveys have been carried out during the 19th century, following the rise of modern hydrography (David, 2008; Davey, 2011), and thus cannot be used for age determination of coastal sediments deposited in the "grey zone" of the last centuries. The aim of this article is to explore to which extent lead line depth soundings acquired before the 19th century can increase the temporal coverage of chronobathymetric sequences. A survey of the late 17th century from western France is presented as a case study. The strengths and weaknesses of the dataset are first identified. Results then serve in the discussion as a basis for more general guidelines in the data processing and interpretation of such old bathymetric data.

\section{Study area}

\subsection{Geography}

The study considers the case of the shallow coastal domain of the Pertuis Charentais area, which is located along the Atlantic Coast of France $\left(46^{\circ} \mathrm{N}, 01^{\circ} \mathrm{W}\right.$; Fig. 1a). The word "pertuis" locally designates the outer marine segment of three main incised valleys (Chaumillon et al., 2008b), which extend inland into large low-lying coastal marshes (Breilh et al., 2013). They include from north to south the Pertuis Breton $\left(260 \mathrm{~km}^{2}\right)$, the Pertuis d'Antioche $\left(450 \mathrm{~km}^{2}\right)$ bounded by rocky shores, and the Pertuis de Maumusson that is a $1.5 \mathrm{~km}$ wide tide-dominated inlet (Bertin et al., 2004, 2005). The Marennes-Oléron Bay is a two-entrance estuarine bay that is both connected to the Pertuis d'Antioche and Pertuis de Maumusson (Allard et al., 2010). The Pertuis Charentais area is a typical representative of rocky coast incised valleys (Chaumillon et al., 2008b, 2010), corresponding to transitional environments between flat depositional coasts (deep rock basement) and high relief rias (outcropping rock basement).

\subsection{Bathymetry}

In the following, bathymetry of the Pertuis Charentais is described relative to the $\mathrm{ZH}$ vertical datum, which is currently in use in France for navigational purposes and refers to the Lowest Astronomical Tide level (LAT). The Pertuis Charentais sea floor is shallow, with more than $90 \%$ of its total area between 0 and $-20 \mathrm{~m} \mathrm{ZH}$ and $65 \%$ between 0 and $-10 \mathrm{~m}$ ZH (Fig. 1a).

The Pertuis Breton and Pertuis d'Antioche can be divided into four main bathymetric domains (Chaumillon and Weber, 2006, Fig. 1a and b) including from west to east:

- the outer shoals (maximum depth $-20 \mathrm{~m} \mathrm{ZH}$ ) with a slope of about $0.1 \%$.
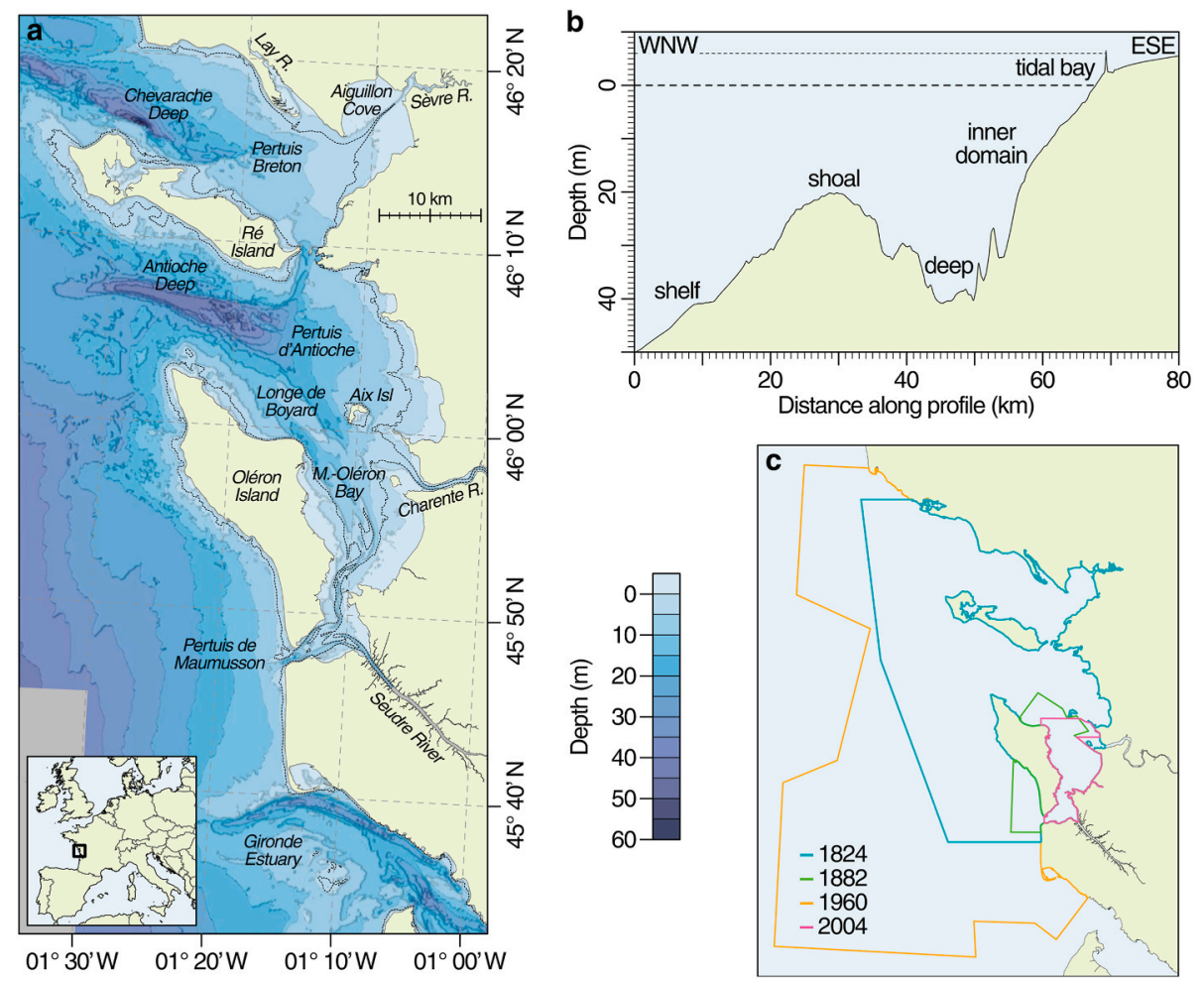

Fig. 1. Location map. (a) Bathymetric map of the area with toponyms mentioned in the text. (b) Depth cross section. (c) Overlap of historical bathymetric datasets. 
- two narrow NW-SE oriented trenches including the Chevarache Deep (maximum depth $-60 \mathrm{~m} \mathrm{ZH}$ ) and the Antioche Deep ( $-47 \mathrm{~m}$ $\mathrm{ZH})$ for the Pertuis Breton and the Pertuis d'Antioche, respectively.

- inner domains ranging between with $-20 \mathrm{~m}$ and $0 \mathrm{~m} \mathrm{ZH}$, with a slope of about $0.2 \%$

- estuarine bays characterised by extensive intertidal mudflats, with a slope not greater than 0.05

Tidal channels in the Marennes-Oléron Bay have water depth ranging from about $-18 \mathrm{~m}$ in the Maumusson Inlet to $-2 \mathrm{~m} \mathrm{ZH}$ elsewhere.

Historical bathymetric datasets have already been used to constrain the morphological evolution of the study area (Fig. 1c, Bertin et al., 2004, 2005; Bertin and Chaumillon, 2005, 2006; Chaumillon et al., 2008a; Allard et al., 2010; Guérin et al., 2016). They include two large-scale surveys carried out in 1824 (Beautemps-Beaupré survey, lead line) and 1960 (SHOM Mannevy survey, acoustic mono-beam sounder), as well as two other surveys focused on the Marennes-Oléron bay and carried out in 1882 (Germain, Renaud and Laporte survey, lead line) and in 2003 (DDE17 survey, acoustic mono-beam sounder; Allard et al., 2010).

\subsection{Hydrodynamics and sediment}

The Pertuis Charentais area is affected by semi-diurnal tides ranging from $2.5 \mathrm{~m}$ (mean neap tides) to $5.1 \mathrm{~m}$ (mean spring tides), the average tidal range being $4.0 \mathrm{~m}$ (SHOM, 2019). Low to moderate offshore wave conditions prevail (height $\mathrm{Hs}_{1 / 4}=0.8-2.5 \mathrm{~m}$, period $\mathrm{Tp}_{1 / 4}=6-12 \mathrm{~s}$, direction Dirp $1 / 4=274-292^{\circ}$ ), but winter storms originating from the North Atlantic Ocean can episodically produce waves larger than $9 \mathrm{~m}$ (Bertin et al., 2008). Owing to complex hydrodynamic and bathymetric interactions within the Pertuis, wave energy along the coast is decayed by almost one order of magnitude relative to offshore conditions (Allard et al., 2008). Resuspension of fine sediments in shallow waters of the Pertuis Charentais is mostly driven by wind waves, contributing to high turbidity of the water column during storms (Gouleau et al., 2000).

Four small coastal rivers (mean water discharge ranging from 2 to $100 \mathrm{~m}^{3} \mathrm{~s}^{-1}$, Chaumillon and Weber, 2006) contribute to minor direct freshwater and suspended sediment input, the largest being the Charente River. As much as $85 \%$ of suspended sediments are indirectly provided by the Gironde estuary, which is located $35 \mathrm{~km}$ southwards of the Pertuis de Maumusson (Fig. 1a), owing to northeastwards deviation of its turbid plume into the Marennes-Oléron Bay (Dabrin et al., 2014).

Sediment distribution on the Pertuis Charentais sea floor follows complex spatial patterns inherited from Holocene environmental changes and present-day hydrodynamics (Poirier et al., 2010). Coarse-grained sediments (fine sands to gravels) mostly accumulate on the shoals and inner domain slopes (Weber et al., 2004a, 2004b, Chaumillon and Weber, 2006), which feature subtidal hydraulic dunes (Chaumillon et al., 2004). In the Marennes-Oléron bay, sand bodies include a type 2 estuary mouth sandbank (following Dyer and Huntley, 1999) called the Longe de Boyard at the northern entrance (Chaumillon et al., 2002, 2008a), flood-dominated sandbanks in the central channels (Allard et al., 2010) and ebb-dominated inlet deltas at the Pertuis de Maumumusson southern entrance (Bertin et al., 2004, 2005).

The coarse-grained sediment fill is capped by very fine silts extending from intertidal flats towards the Chevarache and Antioche deeps. The silt drape is about $820 \mathrm{~km}^{2}$ large and on average $1-1.5 \mathrm{~m}$ thick, up to more than $5 \mathrm{~m}$ in the Marennes-Oléron bay depocentre, lying unconformably over Holocene sand-dominated deposits (Allard et al., 2010). Fine-grained sediment supply and trapping increased since the late 18th century as a likely result of deforestation on catchments (Poirier et al., 2011), coastal marsh reclamation (Allard et al., 2010) and oyster farming (Bertin and Chaumillon, 2006).

\subsection{Historical context}

Coastal hydrography in France was developed from the mid 17th century, under the reign of the king Louis XIV (Ritchie, 1991). The maritime policy of this primarily rural country was devised by the king's chief minister Jean-Baptiste Colbert. It was justified by a tense geopolitical context following naval conflicts, and by economical ambitions to expand French overseas colonies and to promote international trade. In this respect, J.-B. Colbert's cousin Charles Colbert de Terron was commissioned in 1661 to supervise a systematic exploration of the French Atlantic coasts, with the aim of identifying suitable locations for building deep water harbours and military shipyards (Bousquet-Bressolier, 2003; Acerra, 2011; Sauzeau, 2018). The Pertuis Charentais coastline is interspersed with a dense network of military fortifications erected since the early 17th century (Faucherre, 1994). The key element of this defense plan is the Rochefort war shipyard located in the Charente River estuary, and founded in 1666 (Acerra, 2011).

In the study area, the Colbert de Terron survey was carried out by La Favolière (16./17., unknown first name) and published in 1675. Despite the abundance of depth measurements, the chart was not used for this study because copies hosted at the NLF are in a poor preservation state with many illegible soundings, and because the shoreline positioning is notoriously wrong (Bousquet-Bressolier, 2003; Suire, 2011). In 1679, the military engineer Claude Masse (1652-1737) was sent to the Pertuis Charentais to administer coastal fortifications and military facilities. Rightly, Masse considered La Favolière as a talented hydrographer but as a poor land surveyor, and performed complementary topographic surveys between 1688 and 1724 (Bousquet-Bressolier, 2003; Suire, 2011). Combination of the La Favolière and Masse works resulted in a detailed representation of the Pertuis Charentais coasts in these times, providing accurate information about seafloor depth and sediment cover, shoreline evolution, currents and suitability for navigation, among others.

\section{Materials and methods}

\subsection{Cartographic material}

The NLF carried out high-resolution scanning ( $\geq 300 \mathrm{dpi}$ ) of many charts to avoid damage to physical materials, and to facilitate public consultation through the online digital library Gallica (https://gallica. bnf.fr). High-resolution scans of the Masse charts, which were typically $65 \times 90 \mathrm{~cm}$ (approx. Scale 1:30,000), were retrieved from the Gallica digital library. Twelve charts out of a series of twenty contained a dense network of depth soundings and were selected for the study. According to annotations on chart 2 (Table 1), Masse "partly" reproduced depth soundings from La Favolière works. While Masse charts were colourful (Suire, 2011), NLF scanned charts contained little colours and many lead pencil hand annotations, suggesting they were preliminary drafts drawn in 1703 (Fig. 2a). For convenience, the dataset is referred to the 1675 bathymetry in the following.

\subsection{Documentary material}

French historians focused mostly on famous cartographers of the 17th to 19th centuries (see e.g. Chapuis, 1999; Bousquet-Bressolier, 2003), but the theoretical background and practical implementation of depth measurements remain poorly understood for the 17th century. First-hand documentary data were therefore retrieved from available archives in order to better constrain the methodology used by La Favolière and Masse to produce their charts, and in order to provide a critical evaluation of these bathymetric data.

Although the preservation and indexation of hydrographic archives in France is rather satisfactory, documents are very abundant and scattered in several institutions including the NLF, the Navy's Hydrographic and Oceanographic Department (SHOM), the Defence Historical 
Table 1

Historical charts used in the study (see Fig. 3a).

\begin{tabular}{|c|c|c|}
\hline $\begin{array}{l}\text { Chart } \\
\text { number }\end{array}$ & Chart title & Archival Resource Key \\
\hline 1 & Pertuis Breton - Nord de l'Ile de Ré & $\begin{array}{l}\text { 12148/ } \\
\text { btv1b530149456 }\end{array}$ \\
\hline 2 & $\begin{array}{l}\text { Pertuis Breton - L'Aiguillon - Rade de } \\
\text { l'Aiguillon }\end{array}$ & $\begin{array}{l}\text { 12148/ } \\
\text { btv1b53015146z }\end{array}$ \\
\hline 3 & Marans & $\begin{array}{l}\text { 12148/ } \\
\text { btv1b53014878d }\end{array}$ \\
\hline 4 & Pertuis d'Antioche & $\begin{array}{l}\text { 12148/ } \\
\text { btv1b530151370 }\end{array}$ \\
\hline 5 & Sud de l'Ile de Ré - La Rochelle & $\begin{array}{l}\text { 12148/ } \\
\text { btv1b53015150p }\end{array}$ \\
\hline 6 & La Rochelle - Châtelaillon & $\begin{array}{l}\text { 12148/ } \\
\text { btv1b53014860d }\end{array}$ \\
\hline 7 & Ile d'Oléron - Ile d'Aix & $\begin{array}{l}\text { 12148/ } \\
\text { btv1b53014962p }\end{array}$ \\
\hline 8 & Embouchure de la Charente & $\begin{array}{l}\text { 12148/ } \\
\text { btv1b53015109n }\end{array}$ \\
\hline 9 & Oléron - Marennes - Arvert & $\begin{array}{l}\text { 12148/ } \\
\text { btv1b530151101 }\end{array}$ \\
\hline 10 & Brouage - Marennes & $\begin{array}{l}\text { 12148/ } \\
\text { btv1b53015031x }\end{array}$ \\
\hline 11 & Embouchure de la Gironde & $\begin{array}{l}\text { 12148/ } \\
\text { btv1b53015154g }\end{array}$ \\
\hline 12 & Royan & $\begin{array}{l}\text { 12148/ } \\
\text { btv1b530148557 }\end{array}$ \\
\hline
\end{tabular}

Service and the French National Archives. Investigation was focused on the collection housed in this latter institution, which included the MAR/ 3JJ "Scientific and geographic observations" subseries containing an abundant and diverse compilation of documents such as ship logs, travel writings, meteorological records and most importantly, technical reports dealing with hydrography.

\subsection{Chart digitising}

The twelve scanned Masse charts containing depth soundings were first assembled in open-source image editor GIMP. Images were cropped, rotated and scaled homothetically to match chart boundaries, represented as thin black lines.

The assembled image was georectified in the RGF93 - Lambert 93 projection system (EPSG code 2154) using open-source software Q-GIS 3.8 (QGIS Core Team, 2020). In first order, Ground Control Points (GCPs) needed for the georectification process were circle or cross markers symbolising villages, which were assumed to relate to parish churches. Coordinates of churches were extracted from topographical database BD TOPO (Institut Géographique National, IGN). Some of these buildings were later destroyed during the French Revolution (1789-1799). In their absence, GCPs were placed at the centre of the villages and also, depending on the context, on other historical buildings or track and road intersections extracted from BD TOPO, but never onto naturally evolving objects such as sandy shorelines or rivers. Second-order GCPs were constructed following simple geometry rules (triangle midpoints, intersecting circles, parallel segments, etc ...) from the network of first-order GCPs. The assembled image was warped with Thin Plate Spline deformation. Thin Plate Spline transformation moves referenced pixels to the exact geographical location of GCPs. The method favours local accuracy but may induce unrealistic image distortion, which was limited here as a high number of GCPs were defined.

After image georectification, the shoreline and the Lowest Astronomical Tide water level (LAT) that are represented on charts as thick pale blue lines (Fig. 2a), and the depth soundings were manually digitised to produce a georeferenced representation of the Pertuis Charentais coast and seafloor depth. Zero depth points were manually added along the LAT line with a spacing of about $400 \mathrm{~m}$, in order to constrain the horizontal and vertical extent of the bathymetric dataset. Depth soundings were expressed in the deprecated "pied du Roi" length unit (King's foot, hereafter pdR) relative to the LAT, according to annotations on chart 2 (Table 1 ).

\subsection{Error analysis}

Depth sounding data were processed with open-source software $\mathrm{R}(\mathrm{R}$ Core Team, 2018), including raster (Hijmans, 2019), rgdal (Bivand et al., 2019), rgeos (Bivand and Rundel, 2019) and sp (Pebesma and Bivand, 2005) packages for handling geospatial data. Despite the recognised quality of the La Favolière hydrographic and Masse topographic works (Bousquet-Bressolier, 2003; Suire, 2011), large horizontal and vertical positioning errors were legitimately expected for such old surveys.

Horizontal errors were estimated by building a Voronoi diagram from the set of depth sounding points. Voronoi diagram partitions a plane into cells that correspond to the equilibrium area of influence between each point. It was assumed that the true geographical position of each depth sounding was likely within its associated Voronoi cell, i.e. that two depth soundings could not have been recorded at the same location.

Vertical unit and errors were estimated by assuming the equivalence of depth values between the 1675 and 1960 bathymetric surveys above subtidal rocks outcropping on the Pertuis Charentais seafloor. This method was successfully applied to the 1824 and 1882 bathymetric surveys of the area (Bertin et al., 2004; Bertin and Chaumillon, 2005; Allard et al., 2010). Subtidal rocks were mapped by Weber and Garlan (2003) from a combination of various data, including the 1824 lead line seafloor sediment survey, modern surface grab samples and side-scan sonar imagery. The 1675 depth sounding points located above subtidal rocky outcrops were selected. The 1960 bathymetric dataset was averaged at the scale of the Voronoi cells associated with rocky outcrops. Linear regression between the 1675 and 1960 depth values provided an estimate of the correspondence between the presumed pdR unit and the metre, and standard deviation of the residuals provided an estimate of the vertical error that should be expected.

\subsection{Interpolation}

Depth soundings were interpolated onto a continuous grid (100 m resolution) using the Akima spline interpolation method implemented in R package akima (Akima and Gebhardt, 2016). The method, which relies on piecewise third-order polynomials, is suited for irregularly spaced points and it is insensitive to outliers. Unlike more popular GIS interpolation methods like kriging or inverse-distance weighting, Akima spline interpolation can take into account small samples of points (minimum of 5) and does not produce unnatural wiggles in the interpolated surface (Akima, 1978).

Horizontal and vertical errors in the positioning of depth soundings were taken into account for interpolation, following the rationale developed by Jakobsson et al. (2002). Sounding points were interpolated after they were randomly moved, the process being iterated 100 times. At each iteration, sounding points were randomly moved horizontally within their Voronoi cell, and vertically based on the residual standard deviation of the linear regression between the 1675 and 1960 depths of rocky outcrops. The 100 interpolated grids were stacked and averaged to produce the final 1675 bathymetric dataset. Spatial randomisation and Akima interpolation algorithms were computationally demanding, so they were run in parallel with the doParallel and foreach $\mathrm{R}$ packages (Microsoft and Weston, 2019a, 2019b).

\section{Results}

\subsection{Documentary data}

The oldest document hosted at the French National Archives in the MAR/3JJ subseries is indexed under the reference MAR/3JJ/1 file 2, 

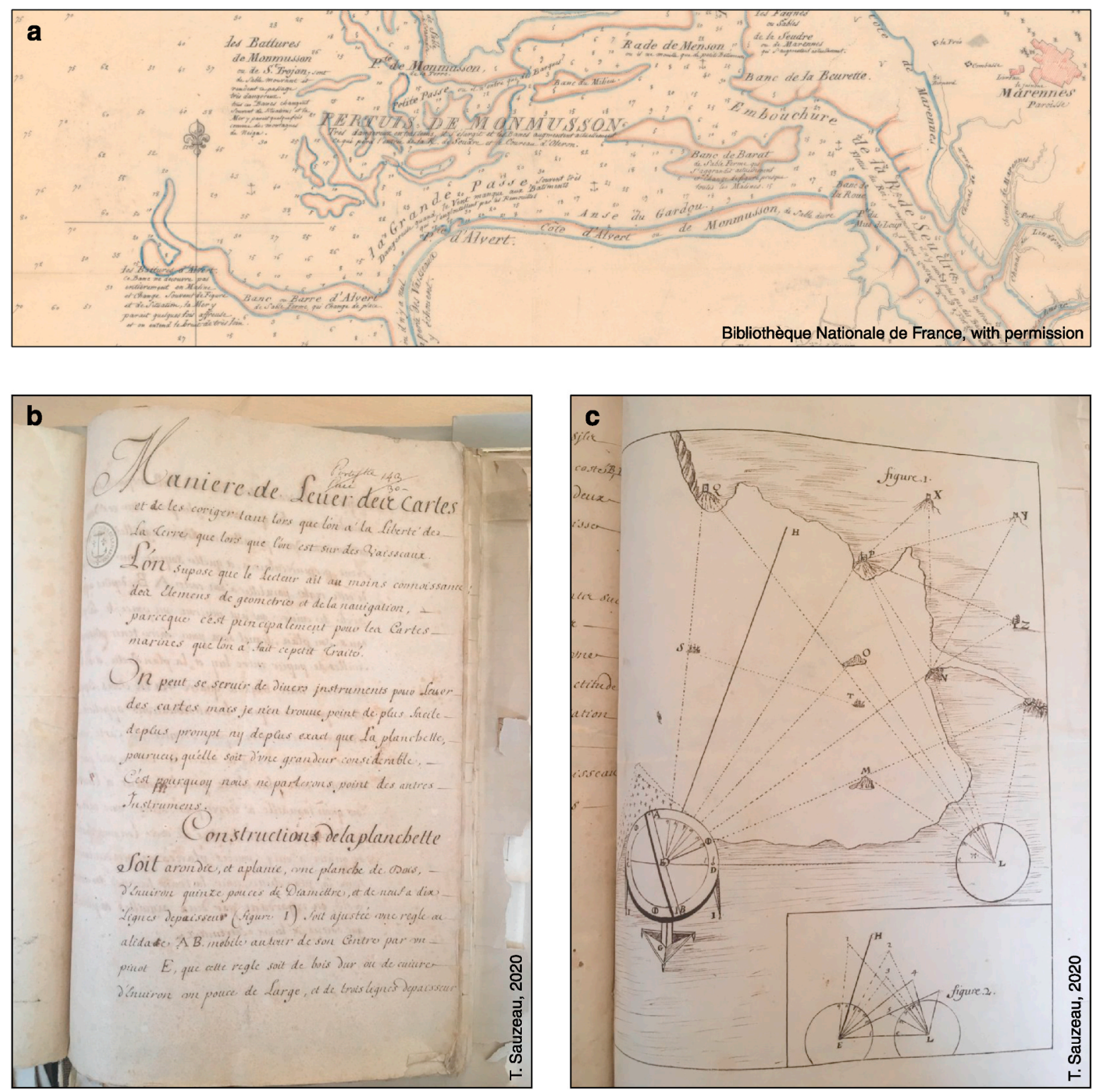

Fig. 2. Cartographic and documentary material. (a) Excerpt from Masse chart number 9 (Table 1). Bibliothèque Nationale de France, with permission. (b) Introductory page of the MAR/3JJ/1 manuscript. Note the handwriting style typical of the late 17th century. (b) Angle measurements, with a depiction of the geometrical plane table at the bottom left corner. Photos by T. Sauzeau.

and dated "around 1670" according to the archive catalogue. It is a small, anonymous 62 page manuscript entitled "Method for lifting nautical charts" (Fig. 2b). The manuscript is divided into 14 sections, starting with preliminary recommendations for building a plane table equipped with an alidade ("planchette" in French; Fig. 2c), the device being the author's favorite for carrying out topographic surveys given "its ease of use, simplicity and accuracy". The sections provide the reader with detailed instructions to use the plane table, to determine the latitude and longitude of a location, to build marine charts in both nearshore and open-ocean settings, and to assess the quality of the charts. However the MAR/3JJ/1 manuscript does not refer to any kind of information relative to the measurement of water depths. It is therefore a manual of geometrical geodesy applied to coastal and marine areas, but not a treatise in hydrography in a strict sense.

\subsection{Horizontal errors}

The twelve Masse charts (Fig. 3a) were georectified with 268 Ground Control Points (Fig. 3b). An overall good correspondence between the
1675 and the present day rocky shorelines is observed, with a deviation not greater than $80 \mathrm{~m}$. A total of 4586 depth soundings covering an area of about $1480 \mathrm{~km}^{2}$ were manually digitised. With the exception of 1957 additional zero depth values placed along the LAT line, this corresponds to an average density of about 3 depth sounding points per $\mathrm{km}^{2}$. As a comparison, the 1824 and 1960 bathymetric surveys have average densities of 45 and 129 points per $\mathrm{km}^{2}$, respectively.

Density of the 1675 bathymetric survey increases up to 13 points per $\mathrm{km}^{2}$ in the vicinity of military harbours and in the northern MarennesOléron bay. Conversely density decreases to less than 1 point per $\mathrm{km}^{2}$ in the central part of the Pertuis Breton and Pertuis d'Antioche, as distance to the shoreline increases. The minimum distance between two neighbouring points, to which the size of Voronoi cells is related, ranges between 82 and $1745 \mathrm{~m}$, the average being $410 \pm 190 \mathrm{~m}$.

\subsection{Vertical errors}

Sounded depth ranges between 1 and 165 pdR relative to the $\mathrm{ZH}$ vertical datum (Fig. 3c). Above subtidal rocky outcrops, a statistically 


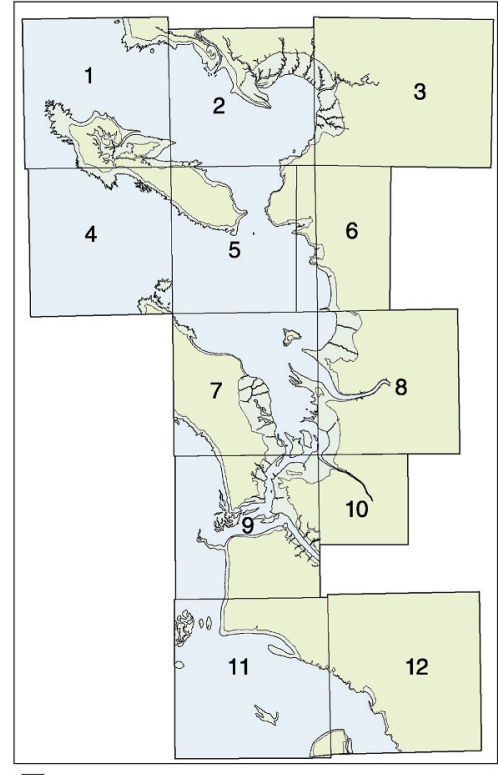

$\square$ map

$\oplus$ Ground Control Point b

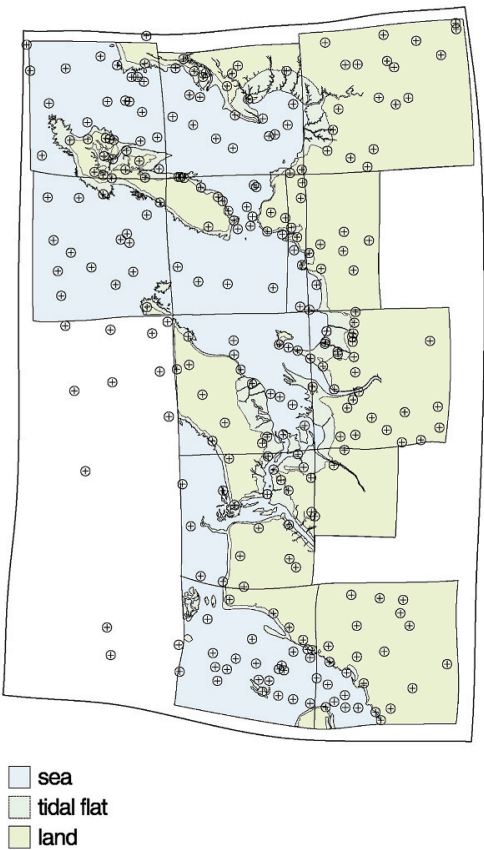

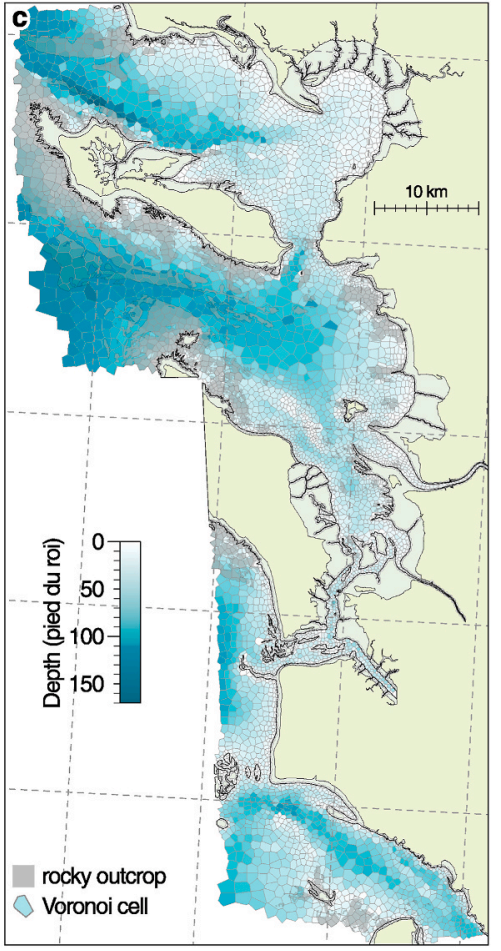

Fig. 3. Data processing. (a) Assembled historical charts prior to georectification (see Table 1). (b) Georectified chart with digitised coastline and LAT. (c) Voronoi cells and depth values in "pied du Roi" unit.

significant linear relationship is found between the 1675 depth soundings expressed in pdR and the reference 1960 bathymetry expressed in meters and averaged at the scale of Voronoi cells (Fig. 4a; $R^{2}=0.70, p<$ $0.001)$. Regression slope of the linear regression model gives a value of $0.242 \mathrm{~m}$ for the pdR unit (95\% confidence interval 0.233-0.250 m). Zero intercept of is $-0.315 \mathrm{~m}$, which implies that the vertical distance of subtidal rocks to the LAT datum was greater in 1960 than in 1675. Relative to the time span between the two surveys (285 years), this represents a shift of $+1.11 \mathrm{~mm}$. $\mathrm{a}^{-1}$. The $1 \sigma$ standard deviation of the residuals indicates a vertical sounding error of $\pm 4.47 \mathrm{~m}$ (Fig. 4a). Absolute residual values increase with depth by about $0.3 \mathrm{~m}$ per meter on average, implying that deep rocky outcrops were less accurately sounded than shallow ones.

As a comparison, the $1 \sigma$ vertical error is $\pm 1.05 \mathrm{~m}$ and the absolute deviation is $0.06 \mathrm{~m}$ per meter on average when the same approach is applied to 1824 depth soundings (Fig. 4b). Vertical stability of rocky outcrops was also checked after grid interpolation of the 1675 depth soundings, by comparing the 1675 and 1824 interpolated bathymetries with the 1960 reference one (Fig. $4 \mathrm{c}$ and d). Post-interpolation vertical errors were \pm 4.48 and $\pm 1.52 \mathrm{~m}$ respectively, and regression slopes were 0.961 and 0.955 respectively. A correction factor of $1 / 0.961$ and of $1 / 0.955$ was therefore applied to reach a 1:1 correspondence between the 1675 and 1824 interpolated bathymetries with the reference 1960 bathymetry above subtidal rocky outcrops.

Deviation of the 1675 depth soundings from the reference 1960 bathymetry above subtidal rocky outcrops (Fig. 4a) follows a nonrandom, cluster-like spatial pattern with marked transitions (Fig. 5). Residual depth values appear too shallow in the Chevarache deep, the Antioche shoal or the Marennes-Oléron bay (orange shades), and conversely too deep in the north Chevarache inner domain or the Antioche deep (purple shades). This pattern shows that the 1675 depth soundings were not recorded homogeneously, which implies that a spatially-explicit difference bathymetric map should not be computed as is.

\subsection{Large-scale chronobathymetric sequence}

The 1675, 1824 and 1960 bathymetries are therefore compared through hypsometric curves, calculated on the ca. $1100 \mathrm{~km}^{2}$ area shared by the three datasets (Fig. 6). Hypsometric curves appear roughly similar in shape, suggesting that the 1675 bathymetry is overall consistent with the 1824 and 1960 ones. However, a striking feature of the interpolated 1675 bathymetry is the lack of the prominent Antioche Deep, and to a lesser extent of the Chevarache Deep (Fig. 7a, c). These two narrow trenches reach a maximum depth of about -47 and $-60 \mathrm{~m}$ $\mathrm{ZH}$ (as measured in 1960), but do not exceed -32 and $-38 \mathrm{~m} \mathrm{ZH}$ on the 1675 bathymetry, respectively. Misrepresentation of tidal channels is also evident in the northern Marennes-Oléron Bay and in the Gironde Estuary. It is therefore assumed in the following that the 1675 bathymetry is not trustworthy below $-14 \mathrm{~m} \mathrm{ZH}$, the depth beyond which deviation of its hypsometric curve from the 1824 and 1960 ones becomes significant (Fig. 6). It is also assumed that all concave upward features (deeps and channels) were improperly sounded, even though they are located within the domain of validity between -14 and $0 \mathrm{~m} \mathrm{ZH}$.

With as much as $89.2 \%$ of values within the \pm 4.48 m error margin, bathymetric difference between the 1675 and 1824 datasets is unexploitable. The proportion reaches $97.7 \%$ when areas of negative depth difference (erosion) are excluded, as they are an artefact of the misrepresentation of tidal channels that appear shallower than expected on the 1675 bathymetry. The median $1824-1675$ bathymetric change is $+1.34 \mathrm{~m}$ on areas of positive difference, while the median 1960-1824 bathymetric change is $+0.58 \mathrm{~m}$. Relative to the time span between each survey, the 1824-1675 bathymetric difference was therefore about 2 times greater on average than the 1960-1824 bathymetric difference.

\subsection{Case study: the Longe de Boyard sand ridge}

This section describes the case of the Longe de Boyard (LdB) sand ridge (Fig. 8). It was chosen (1) because the Longe de Boyard is located in the northern Marennes-Oléron bay, which is shallow $(>-14 \mathrm{~m})$ and 
a

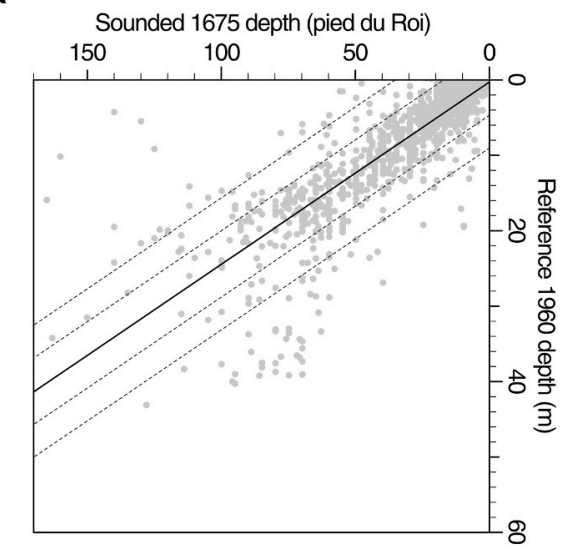

c

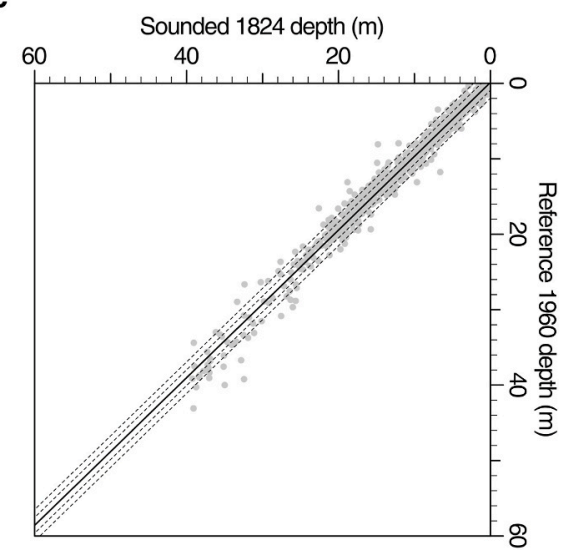

b

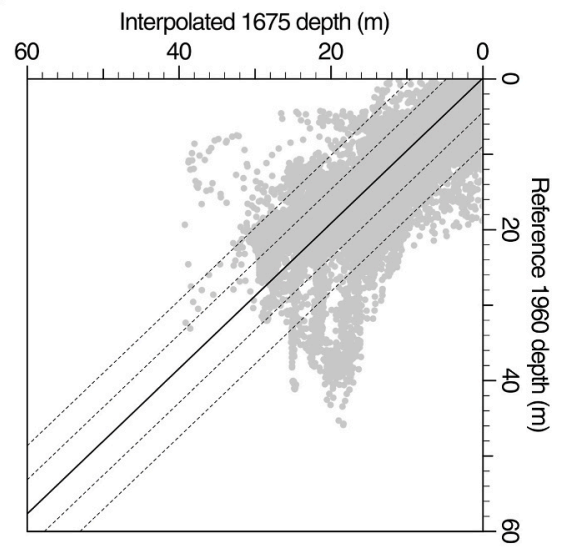

d

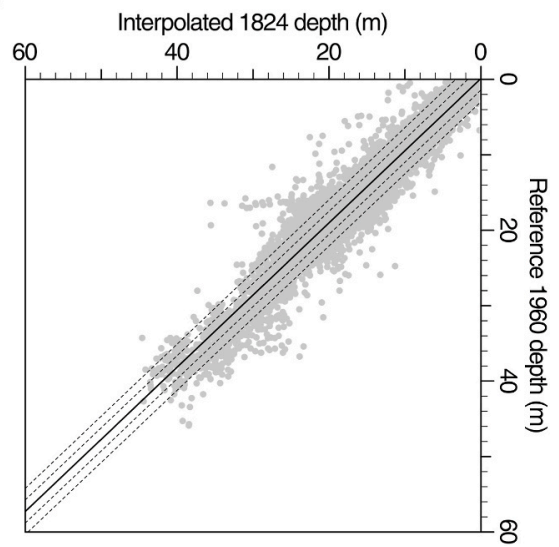

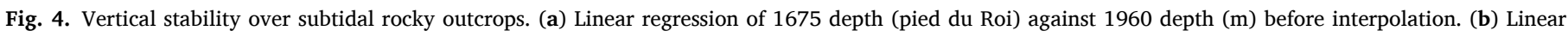

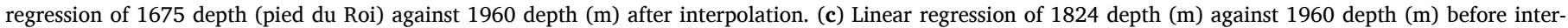
polation. (d) Linear regression of 1824 depth (m) against 1960 depth (m) after interpolation.

has a higher density of depth sounding points (Fig. 3c); (2) because the Longe de Boyard is located nearby subtidal rocky outcrops with relatively low vertical error, suggesting depth was correctly measured in the area (Fig. 5); and (3) because the Longe de Boyard experienced conspicuous morphological changes within historical time scales.

Interestingly, the Longe de Boyard sand ridge in the late 17th century was located more seaward and was split in two parts, including the "Banc de la Longée" to the north and the "Banc de Boyard" to the south (Fig. 8a). The two banks were separated by a shallow ( -5 to $-3 \mathrm{~m} \mathrm{ZH}$ ), narrow channel where "only small boats shall sail", as noted by Masse on chart 7 (Table 1). On the 1824 bathymetric map, the two toponyms "La Longe" and "Le Boyard" remained, although the sand ridge formed a single entity at that time (Fig. 8b). The toponyms were eventually merged and deformed until the sand ridge is now known as the "Longe de Boyard" (Fig. 8c). There is good confidence in this representation of the Longe de Boyard, because original small-scale charts of the early to mid 18th century retrieved from Gallica digital library also depict two distinct sand ridges with similar morphologies.

Morphology of the Longe de Boyard bears some affinities with that of the underlying bedrock (Fig. 8a, d), which topography was previously reconstructed from extensive very high-resolution seismic surveys (Chaumillon et al., 2002). Bedrock below the Longe de Boyard consists of a NW-SE oriented $2 \mathrm{~km}$ wide, $10 \mathrm{~km}$ long topographic high with 4 dome-shaped features labelled A to $\mathrm{D}$. The A to $\mathrm{C}$ domes have a local maximum altitude of about $-8 \mathrm{~m} \mathrm{ZH}$, while the $\mathrm{D}$ dome peaks to about $-3 \mathrm{~m} \mathrm{ZH} \mathrm{(Fig.} \mathrm{8d).} \mathrm{The} \mathrm{bulk} \mathrm{of} \mathrm{the} \mathrm{northern} \mathrm{"Banc} \mathrm{de} \mathrm{la} \mathrm{Longée"} \mathrm{in} 1675$ was located in a trough between A and B domes, and bulk of the southern "Banc de Boyard" was located in a trough between C and D domes (Fig. 8a, d, e). Top of the sand ridge eventually flattened from 1824 onwards, and eroded between 1824 and 1960. Location of the south-eastern ebb shield remained constrained by the D bedrock dome (Fig. 8e).

Volume of the Longe de Boyard above $-5 \mathrm{~m} \mathrm{ZH}$ was estimated to approximately $26.310^{6} \mathrm{~m}^{3}$ in 1675 , decreasing to $22.010^{6} \mathrm{~m}^{3}$ in 1824 and to $14.010^{6} \mathrm{~m}^{3}$ in 1960 . Relative to the time span between each survey, the sand ridge therefore lost about $29,500 \mathrm{~m}^{3}$ of sediment each year between 1675 and 1824, as opposed to a two-times greater loss of about 58,000 $\mathrm{m}^{3}$ per year between 1824 and 1960 .

\section{Discussion}

\subsection{Documentary data}

The National Archives catalogue dates the MAR/3JJ/1 manuscript "around 1670", which is confirmed by the handwriting style, and the numerous references to the Picard and La Hire geodesical works, which were carried out from 1671 to 1681 (Pelletier, 2013). The manuscript is therefore contemporary to the La Favolière chart. References to Picard and La Hire also imply that the manuscript was written by an authoritative figure who was in close relation with the members of the French Academy of Sciences founded in 1666, and who was aware of the many ongoing topographic and hydrographic surveys initiated by the king's chief minister Jean-Baptiste Colbert. The MAR/3JJ/1 manuscript is therefore a first-hand, trustworthy source of knowledge that helps in the interpretation of the 1675 bathymetric dataset.

A negative, yet important contribution of the MAR/3JJ/1 


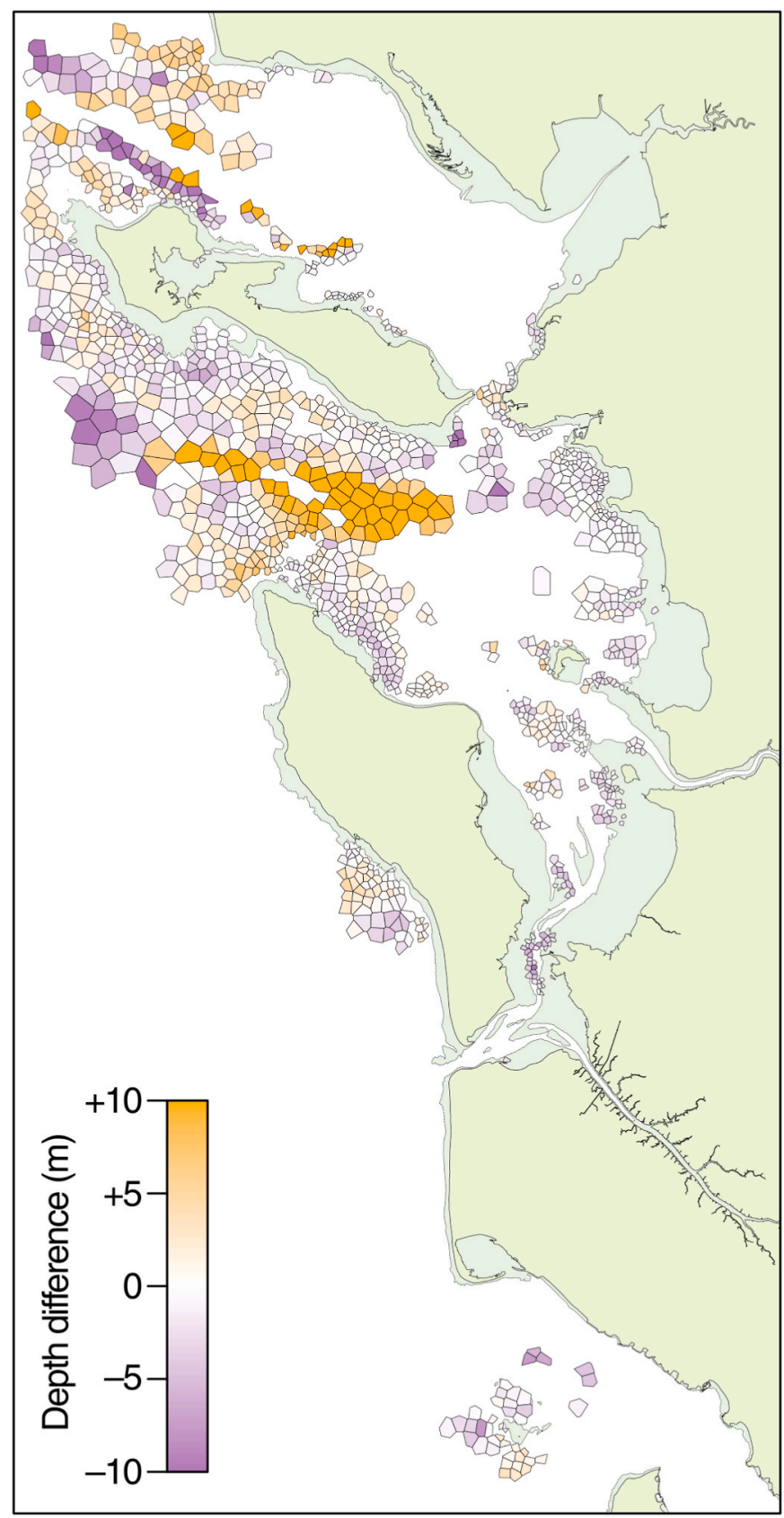

Fig. 5. Distance of 1675 depth soundings to the 1960 reference bathymetry over subtidal rocky outcrops. Values correspond to residuals in Fig. 4a.

manuscript is the total absence of information regarding the measurement of water depths. We therefore hypothesise that neither La Favolière nor Masse acquired bathymetric data on the field, as they lacked a standardised methodology issued by the Academy of Sciences for this purpose. Instead, they compiled depth soundings taken by local sailors and coasting pilots over an unknown period of time, probably ranging from a few years to a few decades. The 1675 bathymetric dataset is therefore by no means the result of a homogeneous hydrographic survey.

This assumption is supported by several results which are discussed in the following.

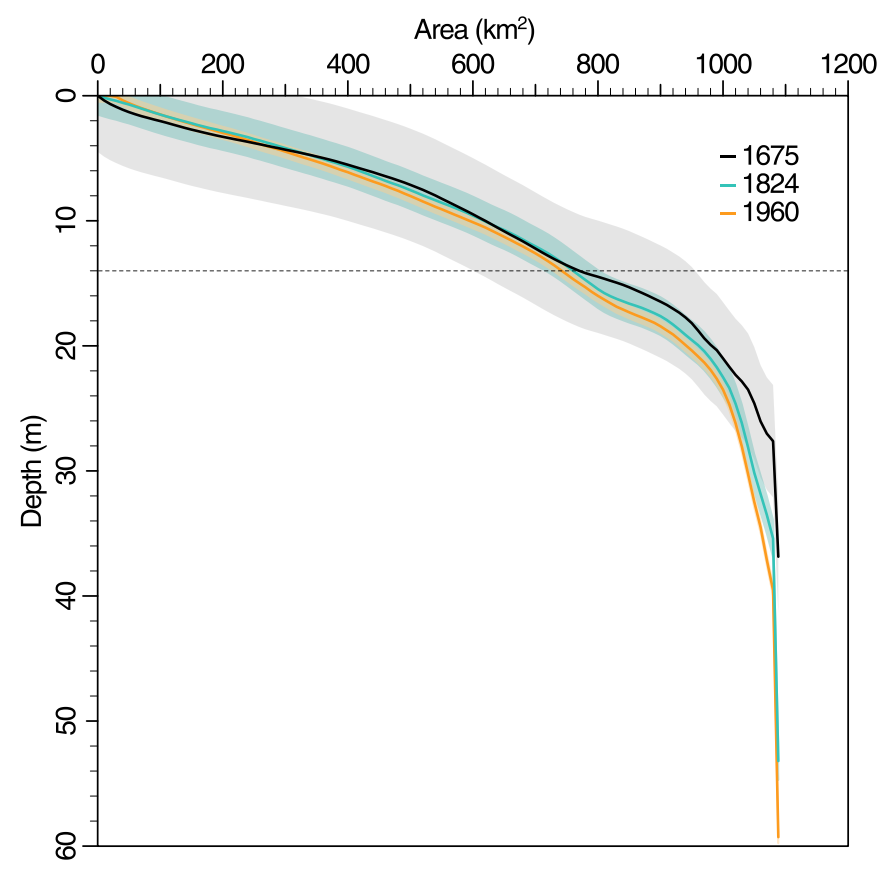

Fig. 6. Hypsometric curves of the 1675,1824 and 1960 bathymetries. Note the deviation of the 1675 curve to the 1960 reference beyond depths of $-14 \mathrm{~m} \mathrm{ZH}$.

\subsection{Sources of error}

\subsubsection{Horizontal dimension}

The 1675 bathymetry suffers a poor horizontal resolution compared to the 1824 and 1960 surveys. The large distance between two adjacent sounding points precludes the precise rendering of small-scale bathymetric features, in particular the narrow tidal channels of the MarennesOléron bay. Depth sounding points are denser nearby identified hazards and at the entrance of major harbours, which confirms they were primarily acquired for navigational purposes.

\subsubsection{Vertical dimension: datum}

The shift of $+1.11 \mathrm{~mm} . \mathrm{a}^{-1}$ in the LAT datum between the 1675 and 1960 surveys would have resulted from changes in tide parameters and relative sea level variations. In the Pertuis Charentais, relative sea level change has been estimated to $+1.30 \pm 0.32 \mathrm{~mm}$. $\mathrm{a}^{-1}$ from tide gauge records starting in 1824 (Gouriou et al., 2013), which is consistent with our value.

\subsubsection{Vertical dimension: unit}

Water depths are reported in the deprecated "brasse" (fathom) unit on the La Favolière chart and in the "pied du Roi" unit (King's foot, pdR) on the Masse chart, which supports the lack of a standardised methodology for acquisition of bathymetric data. In France, the pdR actually represented about $0.325 \mathrm{~m}$, which corresponds to an average relative difference of $24 \%$ compared to our estimation of $0.242 \mathrm{~m}$ (Fig. 4a). Relationship between the "brasse" and the "pied du Roi" units is straightforward (1 "brasse" = 5 "pied du Roi"), and cannot not explain the observed discrepancy.

We hypothesise that the sailors and coasting pilots who sounded the water depths defined a length standard from their own bodies. Body proportions relative to the total body length were calculated from a compilation of body measurements taken on French male individuals living in the mid 20th century (Olivier et al., 1965). Average body length fluctuated dramatically in France during the late 17th century, depending on food supply and life conditions, and was estimated to 1.63 $\mathrm{m}$ in 1670 (Komlos, 2003). Inferred body proportions among the French male population in 1670 closest to the pdR unit (0.233-0.250 m, Fig. 4a) 

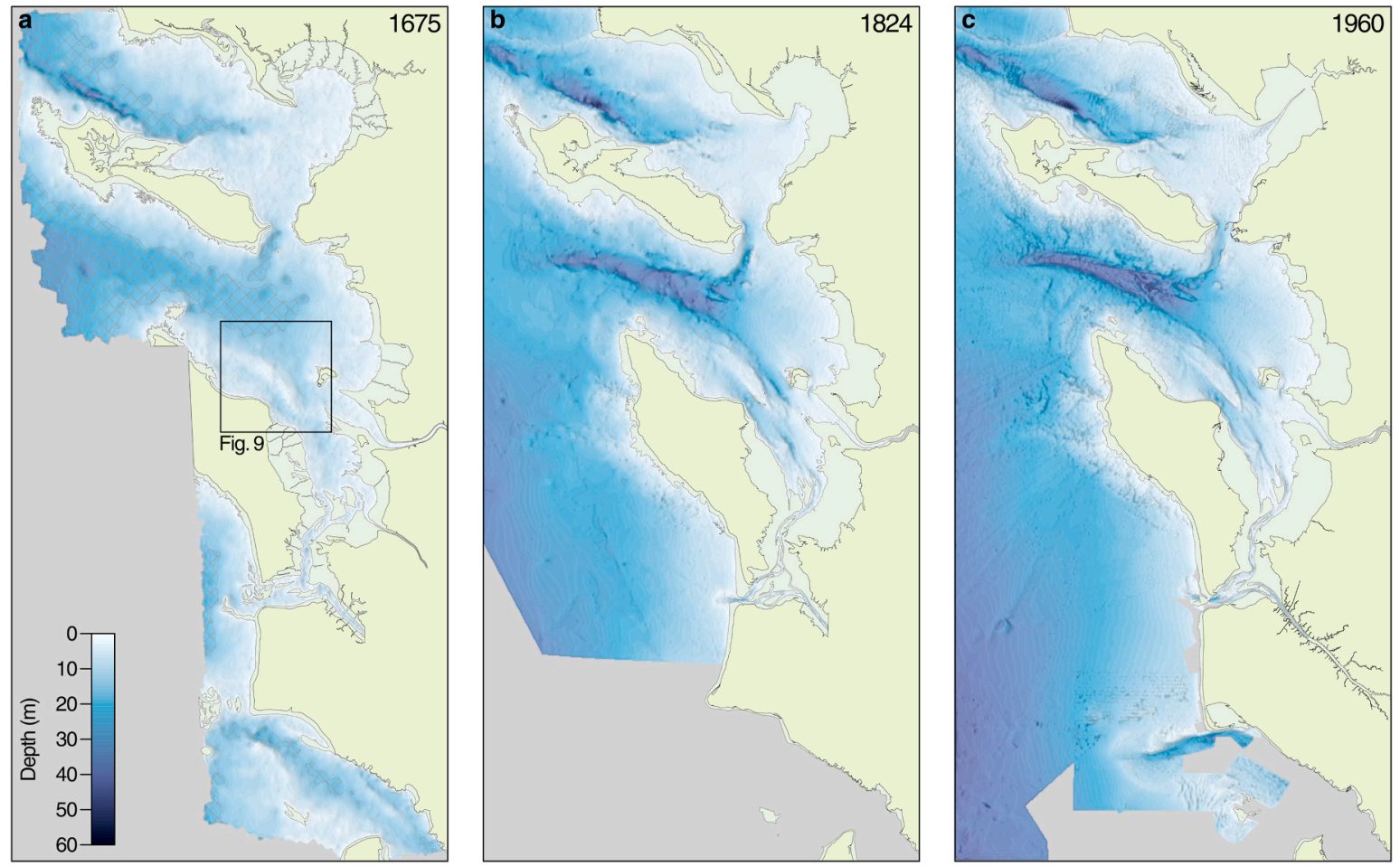

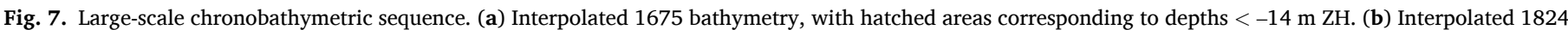
bathymetry. (c) Interpolated 1960 bathymetry.
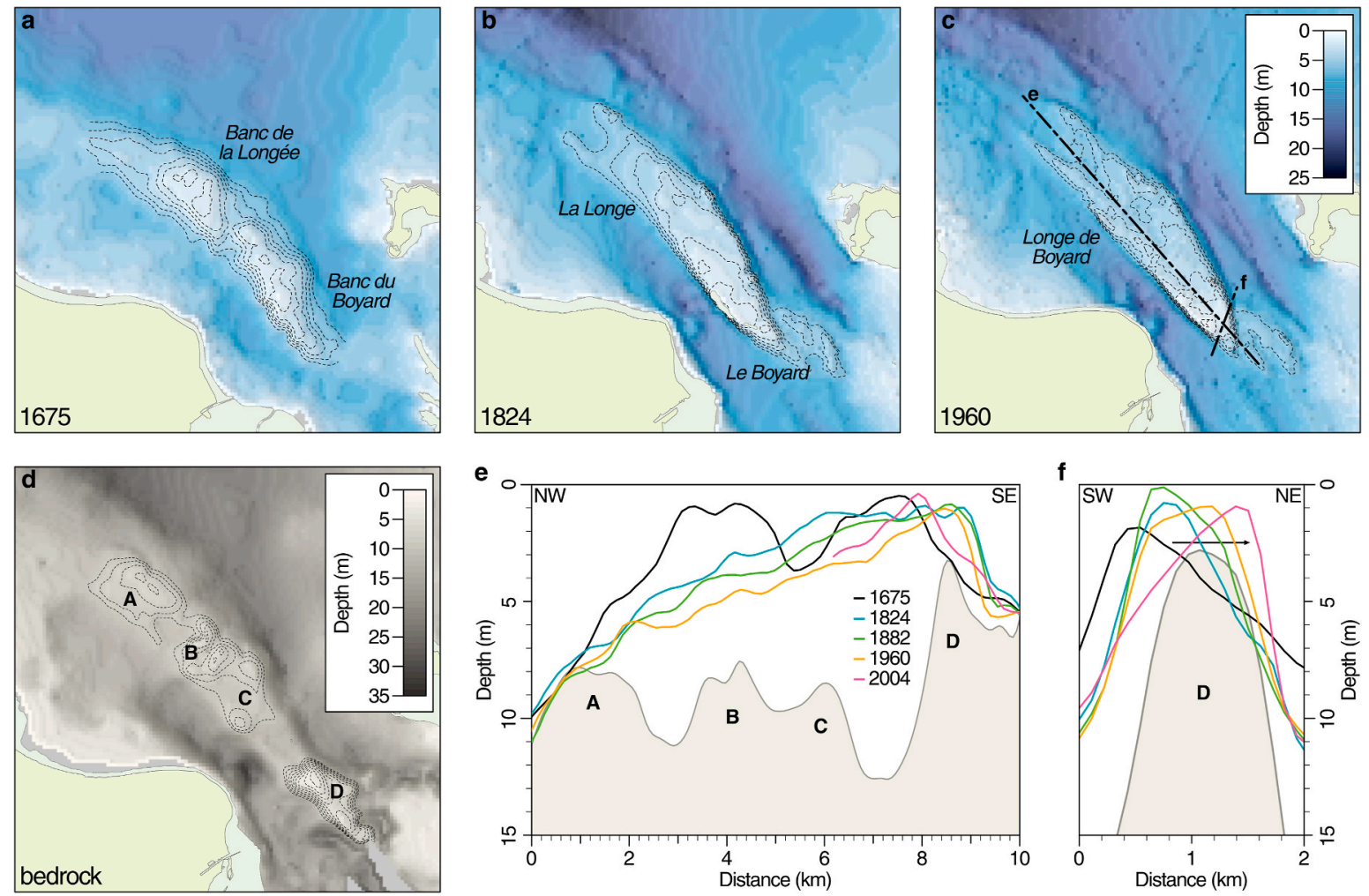

Fig. 8. Evolution of the Longe de Boyard sand ridge. (a) to (c) Bathymetric maps in 1675, 1824 and 1960. (d) Bedrock depth. (e,f) Cross-sections along lines shown in panel c. The 2004 cross-section in panel e is truncated because the Longe de Boyard sand bank was not entirely surveyed in this year.

are the forearm length $(0.239 \mathrm{~m}$, based on a forearm to body length ratio of 0.147 calculated on $\mathrm{n}=1206$ individuals), and to a lesser extent the foot length $(0.254 \mathrm{~m}$, ratio $=0.156, \mathrm{n}=492)$. The forearm would have offered a practical yardstick for these illiterate seamen. Note the word similarity between the "foot" length unit and the "foot" body part, which could have induced confusion. 


\subsubsection{Vertical dimension: resolution and accuracy}

A standardised methodology for tide correction of depth soundings was published by the French hydrographer Beautemps-Beaupré in the early 19th century (Beautemps-Beaupré and Daussy, 1829). Tide correction involved the use of two synchronised pendulum clocks, one being aboard the sounding ship and the other being used inland for sea level recording. Such method was applied as early as 1776 by La Bretonnière and Méchain on the northern French coasts (Beautemps-Beaupré and Daussy, 1829), hence one century after the La Favolière chart was published.

Lack of tide correction would account for $\pm 2.0 \mathrm{~m}$, i.e. $44 \%$ of the vertical error of the 1675 bathymetry, as mean tidal range in the Pertuis Charentais is $4.0 \mathrm{~m}$ (SHOM, 2019). Other sources of error contributing to the poor vertical accuracy are more difficult to quantify, and may include changes in sediment distribution on the sea floor (rocky outcrops buried in 1675), variability in the ill-defined pdR length unit, lateral drift of the sounding ship and lead line, sea level fluctuations induced by waves and atmospheric pressure during depth recording, and erroneous reporting of data by word of mouth.

\subsection{Large-scale chronobathymetric sequence}

Median 1824-1675 bathymetric change is about two times greater than the median 1960-1824 bathymetric change on areas of positive difference, where a better accuracy is expected. A ${ }^{14} \mathrm{C}$-dated sediment core recovered in the eastern Marennes-Oléron bay evidenced a 2-2.5 fold increase in sedimentation rates across the 18th century (Poirier et al., 2011) that is consistent with the overall pre- and post-1824 bathymetric difference median values. The 1675 bathymetry provides additional evidence for increased sediment supply within historical times.

\subsection{Longe de Boyard sand ridge}

Morphological similarity between the Longe de Boyard in 1675 and the underlying rock basement (Fig. 8a,d) provides an additional evidence for bedrock control on sedimentation in the area, in agreement with previous studies focused on tidal channels and inlets (Bertin et al., 2004) and shorelines (Chaumillon et al., 2019). Dome-shaped topographic highs in the bedrock below the LdB could have offered anchoring points that initiated early sedimentation of the sand ridge.

Morphodynamics of the LdB is also controlled by the relative influence of tides and waves (Chaumillon et al., 2002; Bertin and Chaumillon, 2005; Chaumillon et al., 2008a; Guérin et al., 2016). Since 1675, the chronobathymetric sequence evidences a decrease of the LdB volume, a south-eastward migration and a transition from a slightly arcuate to a more linear shape. Previous knowledge on the morphological evolution of the LdB is broadly confirmed and strengthened by the 1675 data. The south-eastward migration and lateral sand accretion is explained by the combined effect of the wave-induced sand transport (Guérin et al., 2016) and the flood-domination in the northern Marennes-Oléron Bay (Bertin and Chaumillon, 2005; Chaumillon et al., 2008a).

At the pluri-annual to decadal time scale, wave-induced sediment supply in the Pertuis Charentais is controlled by external climate drivers, via complex cascading effects on wind speed and wave height in the northeastern Atlantic Ocean. Increased wave-induced sediment supply from about 1710 to 1760 (Poirier et al., 2017) could have fed the LdB with coarse-grained particles and counterbalanced the tide-induced erosional trend, which would explain why LdB sediment loss was two times lower before $1824\left(-29,500 \mathrm{~m}^{3}\right.$ per year $)$ than after $\left(-58,000 \mathrm{~m}^{3}\right.$ per year).

\section{Conclusion}

Beyond its utility for local studies, the 1675 bathymetry of the
Pertuis Charentais provides interesting insights into the processing of depth measurements acquired prior to the rise of modern hydrography. All favourable conditions were met to turn the La Favolière chart into a spatially explicit bathymetric reconstruction of the Pertuis Charentais in the late 17 th century. A few general advices can be inferred from the results described above:

1. Geo-historical context In addition to the inherent talents of the cartographers, the quality of the charts also depends on the overall historical and geographical context, and on the scope for which these charts were made.

2. Documentary data First-hand historical documents provide invaluable information to constrain the methodology deployed to acquire depth measurements, and to assess the quality of these data. In the lack of documentary material, the overall historical context would provide indirect clues.

3. Rocky coast estuary In the absence of major tectonic deformation within historical times, rocky coast estuaries offer a wealth of stable reference points in both the horizontal and vertical dimension, and irregular shorelines facilitate the chart georectification process.

It is unclear whether this approach could be replicated in other areas, as it appears to be strongly site-dependent. This study however demonstrates that marine charts drawn long before modern hydrographic surveys deserve consideration, provided they can be critically assessed, to document the morphodynamical evolution of coastal environments.

\section{Author statement}

Clément Poirier: Conceptualization, Methodology, Formal analysis, Writing - Original Draft, Visualization.

Thierry Sauzeau: Investigation, Resources, Writing - Original Draft, Writing - Review \& Editing.

Eric Chaumillon: Writing - Original Draft, Writing - Review \& Editing.

Bernadette Tessier: Writing - Review \& Editing, Writing - Original Draft Supervision, Project administration, Funding acquisition.

\section{Declaration of competing interest}

The authors declare that they have no known competing financial interests or personal relationships that could have appeared to influence the work reported in this paper.

\section{Acknowledgments}

The authors gratefully thank ECSS editor Steve Mitchell and two anonymous reviewers for their constructive comments and criticism. This work is a contribution to the BLiNiS research project (2013-2014). Financial support was provided by the French Ministry of Environment (Ministère de l'Ecologie, du Développement Durable et de l'Energie, MEDDE) through the LITEAU funding scheme. Geospatial datasets owned by the Institut Géographique National IGN were used in accordance with data license agreement attributed to C.P. and B.T. host institution.

\section{References}

Acerra, M., 2011. La création de l'arsenal de Rochefort. Dix-Septieme Siecle (XVIIe Siècle) 253 (4), 671-676. https://doi.org/10.3917/dss.114.0671.

Akima, H., 1978. A method of bivariate interpolation and smooth surface fitting for irregularly distributed data points. ACM Trans. Math Software 4 (2), 148-159. https://doi.org/10.1145/355780.355786.

Akima, H., Gebhardt, A., 2016. akima: Interpolation of Irregularly and Regularly Spaced Data. R Package Version 0.6-2. https://CRAN.R-project.org/package=akima.

Allard, J., Bertin, X., Chaumillon, E., Pouget, F., 2008. Sand spit rhythmic development: a potential record of wave climate variations? Arçay Spit, western coast of France. Mar. Geol. 253 (3-4), 107-131. https://doi.org/10.1016/j.margeo.2008.05.009. 
Allard, J., Chaumillon, E., Bertin, X., Poirier, C., Ganthy, F., 2010. Sedimentary record of environmental changes and human interferences in a macrotidal bay for the last millenaries: the Marennes-Oléron Bay (SW France). Bull. Soc. Geol. Fr. 181 (2), 151-169. https://doi.org/10.2113/gssgfbull.181.2.151.

Allard, J., Chaumillon, E., Féniès, H., 2009. A synthesis of morphological evolutions and Holocene stratigraphy of a wave-dominated estuary: the Arcachon lagoon, SW France. Continent. Shelf Res. 29 (8), 957-969. https://doi.org/10.1016/j. csr.2008.11.017.

Appleby, P.G., Oldfield, F., 1983. The assessment of $210 \mathrm{~Pb}$ data from sites with varying sediment accumulation rates. Hydrobiologia 103 (1), 29-35. https://doi.org/ 10.1007/BF00028424.

Azevedo, J.W.d.J., de Castro, A.C.L., dos Santos, M.C.F.V., 2016. Siltation rate and main anthropic impacts on sedimentation of the São Luís tidal inlet - state of Maranhão, Brazil. Braz. J. Oceanogr. 64 (1), 9-18. https://doi.org/10.1590/s167987592016092106401.

Beautemps-Beaupré, C., Daussy, P., 1829. Exposé des travaux relatifs à la reconnaissance hydrographique des côtes occidentales de France. Imprimerie Royale, Paris.

Bertin, X., Castelle, B., Chaumillon, E., Butel, R., Quique, R., 2008. Longshore transport estimation and inter-annual variability at a high-energy dissipative beach: St Trojan beach, SW Oléron Island, France. Continent. Shelf Res. 28 (10-11), 1316-1332. https://doi.org/10.1016/j.csr.2008.03.005.

Bertin, X., Chaumillon, E., 2005. Apports de la modélisation sur bathymétries historiques dans la compréhension des évolutions des bancs de sable estuariens. Compt. Rendus Geosci. 337 (15), 1375-1383. https://doi.org/10.1016/j.crte.2005.06.007.

Bertin, X., Chaumillon, E., 2006. The implication of oyster farming in increasing sedimentation rates in a macrotidal bay: the Marennes-Oléron Bay, France. Cah. Biol. Mar. (47), 19-22. https://doi.org/10.21411/CBM.A.6E675E7B.

Bertin, X., Chaumillon, E., Sottolichio, A., Pedreros, R., 2005. Tidal inlet response to sediment infilling of the associated bay and possible implications of human activities: the Marennes-Oléron Bay and the Maumusson Inlet, France. Continent. Shelf Res. 25 (9), 1115-1131. https://doi.org/10.1016/j.csr.2004.12.004.

Bertin, X., Chaumillon, E., Weber, N., Tesson, M., 2004. Morphological evolution and time-varying bedrock control of main channel at a mixed energy tidal inlet: Maumusson Inlet, France. Mar. Geol. 204 (1-2), 187-202. https://doi.org/10.1016 S0025-3227(03)00353-0.

Billy, J., Chaumillon, E., Féniès, H., Poirier, C., 2012. Tidal and fluvial controls on the morphological evolution of a lobate estuarine tidal bar: the Plassac tidal bar in the Gironde Estuary (France). Geomorphology 169-170, 86-97. https://doi.org/ 10.1016/j.geomorph.2012.04.015.

Bivand, R., Keitt, T., Rowlingson, B., 2019. rgdal: Bindings for the 'Geospatial' Data Abstraction Library. R Package Version 1.4-4. https://CRAN.R-project.org/p ackage $=$ rgdal.

Bivand, R., Rundel, C., 2019. rgeos: Interface to geometry engine - open source ('GEOS'), R Package Version 0.5-1. https://CRAN.R-project.org/package $=$ rgeos.

Blott, S.J., Pye, K., van der Wal, D., Neal, A., 2006. Long-term morphological change and its causes in the Mersey estuary, NW england. Geomorphology 81 (1), 185-206. https://doi.org/10.1016/j.geomorph.2006.04.008.

Bousquet-Bressolier, C., 2003. Claude Masse et la cartographie des côtes du Ponant (1688 à 1724). Cahiers Nantais 59, 57-73.

Breilh, J.F., Chaumillon, E., Bertin, X., Gravelle, M., 2013. Assessment of static flood modeling techniques: Application to contrasting marshes flooded during Xynthia (western France). Nat. Hazards Earth Syst. Sci. 13 (6), 1595-1612. https://doi.org/ 10.5194/nhess-13-1595-2013.

Brothers, L.L., Kelley, J.T., Belknap, D.F., Barnhardt, W.A., Andrews, B.D., Maynard, M. L., 2011. More than a century of bathymetric observations and present-day shallow sediment characterization in Belfast Bay, Maine, USA: implications for pockmark field longevity. Geo Mar. Lett. 31, 237-248. https://doi.org/10.1007/s00367-0110228-0.

Chapuis, O., 1999. A la mer comme au ciel. Beautemps-Beaupré \& la naissance de l'hydrographie moderne (1700-1850). Presses de l'Université de Paris-Sorbonne, Paris.

Chaumillon, E., Bertin, X., Falchetto, H., Allard, J., Weber, N., Walker, P., Pouvreau, N. Woppelmann, G., 2008a. Multi time-scale evolution of a wide estuary linear sandbank, the Longe de Boyard, on the French Atlantic coast. Mar. Geol. 251 (3), 209-223. https://doi.org/10.1016/j.margeo.2008.02.014.

Chaumillon, E., Cange, V., Gaudefroy, J., Merle, T., Bertin, X., Pignon, C., 2019. Controls on shoreline changes at pluri-annual to secular timescale in mixed-energy rocky and sedimentary estuarine systems. J. Coast Res. 88 (sp1), 135. https://doi.org/10.2112/ si88-011.1.

Chaumillon, E., Gillet, H., Weber, N., Tesson, M., 2002. Evolution temporelle et architecture interne d'un banc sableux estuarien: la Longe de Boyard (littora atlantique, France). Compt. Rendus Geosci. 334 (2), 119-126. https://doi.org/ 10.1016/S1631-0713(02)01710-8.

Chaumillon, E., Proust, J.-N., Menier, D., Weber, N., 2008. Incised-valley morphologies and sedimentary-fills within the inner shelf of the Bay of Biscay (France): a synthesis. J. Mar. Syst. 72 (1-4), 383-396. https://doi.org/10.1016/j.jmarsys.2007.05.014.

Chaumillon, E., Tessier, B., Reynaud, J.-Y., 2010. Stratigraphic records and variability of incised valleys and estuaries along French coasts. Bull. Soc. Geol. Fr. 181 (2), 75-85. https://doi.org/10.2113/gssgfbull.181.2.75.

Chaumillon, E., Tessier, B., Weber, N., Tesson, M., Bertin, X., 2004. Buried sandbodies within present-day estuaries (Atlantic coast of France) revealed by very high resolution seismic surveys. Mar. Geol. 211 (3-4), 189-214. https://doi.org/ 10.1016/j.margeo.2004.07.004.

Chaumillon, E., Weber, N., 2006. Spatial variability of modern incised valleys on the French Atlantic coast: comparison between the Charente and the Lay-Sèvre incised valleys. In: Incised Valleys in Time and Space. Society for Sedimentary Geology, pp. 57-85. https://doi.org/10.2110/pec.06.85.0057.

Corcho-Alvarado, J.A., Diaz-Asencio, M., Froidevaux, P., Bochud, F., AlonsoHernández, C.M., Sanchez-Cabeza, J.A., 2014. Dating young Holocene coastal sediments in tropical regions: use of fallout ${ }^{239,240} \mathrm{Pu}$ as alternative chronostratigraphic marker. Quat. Geochronol. 22, 1-10. https://doi.org/10.1016/j. quageo.2014.02.001.

Dabrin, A., Schäfer, J., Bertrand, O., Masson, M., Blanc, G., 2014. Origin of suspended matter and sediment inferred from the residual metal fraction: Application to the Marennes Oleron Bay, France. Continent. Shelf Res. 72, 119-130. https://doi.org/ 10.1016/j.csr.2013.07.008.

Dallas, K.L., Barnard, P.L., 2011. Anthropogenic influences on shoreline and nearshore evolution in the San Francisco Bay coastal system. Estuar. Coast Shelf Sci. 92 (1), 195-204. https://doi.org/10.1016/j.ecss.2010.12.031.

Davey, J., 2011. The advancement of nautical knowledge: the hydrographical office, the royal Navy and the charting of the baltic sea, 1795-1815. J. Marit. Res. 13 (2), 81-103. https://doi.org/10.1080/21533369.2011.622869.

David, A., 2008. The emergence of the Admiralty Chart in the nineteenth century. In: 2nd International Symposium on the History of Cartography. Shifting Boundaries: Cartography in the 19th and 20th Centuries. ICA Commission on the History of Cartography, pp. 1-16.

Dyer, K.R., Huntley, D.A., 1999. The origin, classification and modelling of sand banks and ridges. Continent. Shelf Res. 19 (10), 1285-1330. https://doi.org/10.1016/ S0278-4343(99)00028-X.

Faucherre, N., 1994. Les bastions de la mer. Études Rurales 133 (1), 77-86. https://doi. org/10.3406/rural.1994.3455.

Gouleau, D., Jouanneau, J.M., Weber, O., Sauriau, P.G., 2000. Short- and long-term sedimentation on montportail brouage intertidal mudflat, Marennes oléron bay (France). Continent. Shelf Res. 20, 1513-1530. https://doi.org/10.1016/S02784343(00)00035-2.

Gouriou, T., Míguez, B.M., Wöppelmann, G., 2013. Reconstruction of a two-century long sea level record for the Pertuis d'Antioche (France). Continent. Shelf Res. 61-62, 31-40. https://doi.org/10.1016/j.csr.2013.04.028.

Guérin, T., Bertin, X., Chaumillon, E., 2016. Wave control on the rhythmic development of a wide estuary mouth sandbank: a process-based modelling study. Mar. Geol. 380, 79-89. https://doi.org/10.1016/j.margeo.2016.06.013.

Higgins, S.A., Jaffe, B.E., Fuller, C.C., 2007. Reconstructing sediment age profiles from historical bathymetry changes in San Pablo Bay, California. Estuar. Coast Shelf Sci. 73 (1), 165-174. https://doi.org/10.1016/j.ecss.2006.12.018.

Hijmans, R.J., 2019. raster: geographic Data Analysis and Modeling. R Package Version 3.0-2. https://CRAN.R-project.org/package=raster.

Jaffe, B., List, J., Sallenger, A., 1997. Massive sediment bypassing on the lower shoreface offshore of a wide tidal inlet - Cat Island Pass, Louisiana. Mar. Geol. 136 (3-4), 131-149. https://doi.org/10.1016/s0025-3227(96)00050-3.

Jaffe, B.E., Smith, R.E., Foxgrover, A.C., 2007. Anthropogenic influence on sedimentation and intertidal mudflat change in San Pablo Bay, California: 1856-1983. Estuar. Coast Shelf Sci. 73 (1), 175-187. https://doi.org/10.1016/j. ecss.2007.02.017.

Jakobsson, M., Calder, B., Mayer, L., 2002. On the effect of random errors in gridded bathymetric compilations. J. Geophys. Res.: Solid Earth 107 (B12), 2358. https:// doi.org/10.1029/2001jb000616.

Kapsimalis, V., Massé, L., Velegrakis, A., Tastet, J., Lagasquie, M., Paireau, O., 2004. Formation and growth of an estuarine sandbank: Saint-Georges bank, Gironde estuary (France). Journal of Coastal Research Special Issue 41, 27-42.

Komlos, J., 2003. Histoire anthropométrique de la France de l'Ancien Régime. Hist. Econ. Soc. 22 (4), 519-536. https://doi.org/10.3406/hes.2003.2338.

Microsoft, Weston, S., 2019a. doparallel: foreach Parallel Adaptor for the 'Parallel' Package. R Package Version 1.0.15. https://CRAN.R-project.org/package=d oParallel.

Microsoft, Weston, S., 2019. foreach: provides Foreach Looping Construct. R Package Version 1.4.7. https://CRAN.R-project.org/package=foreach.

Miner, M.D., FitzGerald, D.M., Kulp, M.A., 2007. 1880 to 2005 morphologic evolution of a transgressive tidal inlet, Little Pass Timbalier, Louisiana. In: Coastal Sediments '07. American Society of Civil Engineers, pp. 1165-1178. https://doi.org/10.1061/ 40926(239)90.

Olivier, G., Coblentz, A., Ignazi, G., 1965. Les mensurations corporelles des Français et le problème de l'échantillonnage. Bull. Mem. Soc. Anthropol. Paris 7 (3), 221-233. https://doi.org/10.3406/bmsap.1965.1321.

Olsen, J., Ascough, P., Lougheed, B.C., Rasmussen, P., 2017. Radiocarbon dating in estuarine environments. No. 20 in Developments in Paleoenvironmental Research. Springer, Dordrecht, pp. 141-170. https://doi.org/10.1007/978-94-024-0990-1_7. Ch. 7.

Pebesma, E.J., Bivand, R.S., 2005. Classes and methods for spatial data in R. R News, 5 (2), 9-13. https://CRAN.R-project.org/doc/Rnews/.

Pelletier, M., 2013. Les cartes des Cassini - La science au service de l'Etat et des provinces. Comité des Travaux Historiques et Scientifiques CTHS, Aubervilliers.

Poirier, C., Chaumillon, E., Arnaud, F., 2011. Siltation of river-influenced coastal environments: respective impact of late Holocene land use and high-frequency climate changes. Mar. Geol. 290 (1-4), 51-62. https://doi.org/10.1016/j. margeo.2011.10.008.

Poirier, C., Sauriau, P.-G., Chaumillon, E., Bertin, X., 2010. Influence of hydrosedimentary factors on mollusc death assemblages in a temperate mixed tide-andwave dominated coastal environment: implications for the fossil record. Continent. Shelf Res. 30 (17), 1876-1890. https://doi.org/10.1016/j.csr.2010.08.015.

Poirier, C., Tessier, B., Chaumillon, É., Bertin, X., Fruergaard, M., Mouazé, D., Noël, S., Weill, P., Wöppelmann, G., 2017. Decadal changes in North Atlantic atmospheric 
circulation patterns recorded by sand spits since 1800 CE. Geomorphology 281, 1-12. https://doi.org/10.1016/j.geomorph.2016.12.028.

QGIS Core Team, 2020. QGIS geographic information system. Open source geospatial foundation project. https://qgis.org.

R Core Team, 2018. R: A Language and Environment for Statistical Computing. R Foundation for Statistical Computing, Vienna, Austria. https://www.R-project.org.

Reimer, P.J., Bard, E., Bayliss, A., Beck, J.W., Blackwell, P.G., Ramsey, C.B., Buck, C.E., Cheng, H., Edwards, R.L., Friedrich, M., Grootes, P.M., Guilderson, T.P., Haflidason, H., Hajdas, I., Hatté, C., Heaton, T.J., Hoffmann, D.L., Hogg, A.G., Hughen, K.A., Kaiser, K.F., Kromer, B., Manning, S.W., Niu, M., Reimer, R.W., Richards, D.A., Scott, E.M., Southon, J.R., Staff, R.A., Turney, C.S.M., van der Plicht, J., 2013. IntCal13 and Marine 13 radiocarbon age calibration curves 0-50,000 years cal BP. Radiocarbon 55 (4), 1869-1887. https://doi.org/10.2458/ azu_js_rc.55.16947.

Ritchie, G.S., 1991. The history of hydrography - an enlightned European era 1660-1800. Int. Hydrogr. Rev. 1 (68), 7-20.

Sarretta, A., Pillon, S., Molinaroli, E., Guerzoni, S., Fontolan, G., 2010. Sediment budget in the lagoon of venice, Italy. Continent. Shelf Res. 30 (8), 934-949. https://doi.org/ 10.1016/j.csr.2009.07.002.

Sauzeau, T., 2018. L'enquête de 1665 et sa valeur hydrographique pour retracer l'histoire environnementale du coureau d'Oléron. Ann. Bretagne Pays l'Ouest (125-4), 109-130. https://doi.org/10.4000/abpo.4118.

SHOM, 2019. Références Altimétriques Maritimes. Tech. rep., Service Hydrographique et Océanographique de la Marine. https://data.shom.fr.
Suire, Y., 2011. La côte et les marais du Bas-Poitou vers 1700 : cartes et mémoires de Claude Masse, ingénieur du roi. CVRH, La Roche-sur-Yon, France.

Tatekoji, A., Nakamura, R., Shibayama, T., 2016. Influence of historical bathymetric changes due to urbanization on the vulnerability of storm surge in Tokyo bay. Proceedings of the 35th International Conference on Coastal Engineering ICCE 2016. American Society of Civil Engineers (ASCE), pp. 1-12. No. 35.

Watts, A.B., Nomikou, P., Moore, J.D.P., Parks, M.M., Alexandri, M., 2015. Historical bathymetric charts and the evolution of Santorini submarine volcano, Greece. Gcubed 16 (3), 847-869. https://doi.org/10.1002/2014gc005679.

Weber, N., Chaumillon, E., Tesson, M., 2004. Enregistrement de la dernière remontée du niveau marin dans l'architecture interne d'une vallée incisée: le pertuis Breton (Charente-Maritime). Compt. Rendus Geosci. 336 (14), 1273-1282. https://doi.org/ 10.1016/j.crte.2004.07.007.

Weber, N., Chaumillon, E., Tesson, M., Garlan, T., 2004. Architecture and morphology of the outer segment of a mixed tide and wave-dominated-incised valley, revealed by HR seismic reflection profiling: the paleo-Charente River, France. Mar. Geol. 207 (1-4), 17-38. https://doi.org/10.1016/j.margeo.2004.04.001.

Weber, N., Garlan, T., 2003. Les cartes sédimentologiques du SHOM des côtes VendéoCharentaises au 1/50 $0007404 \mathrm{G}$ et 7405G (des Sables-d'Olonne à l'embouchure de la Gironde). In: 9ème Congrès de Sédimentologie, vol. 38, pp. 527-528.

Xie, D., Pan, C., Wu, X., Gao, S., Wang, Z.B., 2017. Local human activities overwhelm decreased sediment supply from the Changjiang River: Continued rapid accumulation in the Hangzhou Bay-Qiantang Estuary system. Mar. Geol. 392, 66-77. https://doi.org/10.1016/j.margeo.2017.08.013. 